\title{
INFLUENCE OF BASIC PROPERTIES OF Mg,Al-MIXED OXIDES ON THEIR CATALYTIC ACTIVITY IN KNOEVENAGEL CONDENSATION BETWEEN BENZALDEHYDE AND PHENYLSULFONYLACETONITRILE
}

\author{
Caridad Noda Pérez \\ Universidade Estadual de Goiás, BR 153 km 98, 75001-970 Anápolis - GO, Brasil \\ José Luiz Fontes Monteiro \\ COPPE, Universidade Federal do Rio de Janeiro, CP 68502, 21941-972 Rio de Janeiro - RJ, Brasil \\ Jose Manoel López Nieto \\ Instituto de Tecnología Química, Universidad Politécnica de Valencia, Avenida. los Naranjos s/n, 46022 Valencia, Espanha \\ Cristiane Assumpção Henriques* \\ Instituto de Química, Universidade do Estado do Rio de Janeiro, Rua São Francisco Xavier, 524, 20550-900 Rio de Janeiro - RJ, \\ Brasil
}

Recebido em 22/11/08; aceito em 9/5/09; publicado na web em 6/10/09

\begin{abstract}
The catalytic performance of Mg,Al-mixed oxides (MO20, MO25 and MO33) derived from hydrotalcites was evaluated in the Knoevenagel reaction between benzaldehyde and phenylsulfonylacetonitrile at 373 and $383 \mathrm{~K}$. The best results were obtained for the sample MO20 that presented the highest basic sites density and external area and the smallest crystallite sizes. The relative amount of basic sites with weak to intermediate strength also played an important role on catalytic performance. By increasing the catalyst content from 1 to $5 \mathrm{wt} . \%$ at $383 \mathrm{~K}$, a complete conversion of the reactants is attained, producing $\alpha$-phenylsulfonylcinnamonitrile with a selectivity of $100 \%$.
\end{abstract}

Keywords: Knoevenagel condensation; Mg,Al-mixed oxides; $\alpha$-phenylsulfonylcinnamonitrile.

\section{INTRODUCTION}

The interest for the development of environmentally friendly solid catalysts has increased in recent years aiming at the replacement of soluble acids $\left(\mathrm{H}_{2} \mathrm{SO}_{4}, \mathrm{HF}\right)$ and bases (alkali metal hydroxides or alkoxides) currently used as catalysts in the synthesis of fine chemicals and pharmaceuticals. The use of heterogeneous catalysts not only allow easy separation and recycle of the catalyst from the reaction mixture, but also reduces the generation of toxic wastes that consist primarily of inorganic salts formed in the reaction or in subsequent neutralization steps. Moreover, the acid or basic sites density and their strength as well as other physico-chemical characteristics of these catalysts can be tailored for the process of interest by adequate preparation procedures and/or by post-synthesis treatments.

As to basic catalysts, $\mathrm{Mg}, \mathrm{Al}-$ mixed oxides derived from hydrotalcites are among the solids that have replaced homogeneous catalysts with considerable success. Hydrotalcites are layered double magnesium-aluminum hydroxides $(\mathrm{LDH})$ with general formula $\left[\mathrm{Mg}_{8-\mathrm{x}} \mathrm{Al}_{\mathrm{x}}(\mathrm{OH})_{16}\left(\mathrm{CO}_{3}^{2-}\right)_{\mathrm{x} / 2}\right] \cdot \mathrm{nH}_{2} \mathrm{O}$, whose structure consists of brucitelike layers, where partial substitution of $\mathrm{Al}^{3+}$ for $\mathrm{Mg}^{2+}$ cations originates an excess of positive charges which are compensated by carbonate anions located along with water molecules in the interlayer space. ${ }^{1,2}$ $\mathrm{The} \mathrm{Al} /(\mathrm{Al}+\mathrm{Mg})$ ratio in hydrotalcites can take values between 0.20 and $0.34 .^{2}$ Thermally treating hydrotalcites induces dehydration, dehydroxylation, and loss of compensation anions, forming the $\mathrm{Mg}$-Al-mixed oxides with basic properties, large specific surface area and a poorly crystallized $\mathrm{MgO}$-type structure. ${ }^{1,3-5}$ So, they are potentially useful as adsorbents and as heterogeneous base catalysts and catalytic supports. The catalytic applications of Mg,Al-mixed oxides obtained from hydrotalcites include base-catalyzed reactions such as aldol condensation of aldehydes and ketones and condensation of the carbonyl group with compounds presenting methylene activated groups (for example, Knoevenagel and Claisen-Schmidt

*e-mail: cah@uerj.br reactions), ${ }^{1,6-20}$ Michael additions, ${ }^{21}$ alkene isomerization, ${ }^{22}$ alkylation of di-ketones and phenols, ${ }^{23,24}$ and alkene epoxidation activated by hydrogen peroxide. ${ }^{25}$

The sulfones present considerable applications as intermediates in organic synthesis, ${ }^{26-29}$ since arylsulfonyl groups can stabilize adjacent carbanion $\mathrm{s}^{30}$ and may easily be removed by hydrolysis, reduction or elimination ${ }^{31}$ and, when appropriate, may be eliminated to introduce carbon-carbon double bonds into organic molecules. ${ }^{32}$ So, they are useful temporary activating groups for various reactions.

The base-catalyzed Knoevenagel condensation of arylsulfones and aldehydes is the most convenient method for synthesizing unsaturated arylsulfones. ${ }^{33}$ The first step of the reaction is the abstraction of a proton from the phenylsulfonylalkane molecule usually catalyzed by strong bases such as butyllithium, ${ }^{34}$ lithium diisopropylamide ${ }^{35}$ or sodium hydride. ${ }^{36}$ However, the deprotonation depends on the presence of adjacent electron-withdrawing groups such as ester, nitrile or ketone. ${ }^{33}$ The recent concern about the environment is increasing the interest in the development of clean and economic process for the production of fine chemicals. In this context, solid base catalysts have received increasing attention as substitutes for the highly pollutant liquid catalysts in organic reactions. This replacement has several technical advantages, such as little or no corrosion, easy handling and separation, catalysts reutilization, and reduction of the amount of toxic wastes.

Thus, the Mg,Al-mixed oxides derived from hydrotalcites, which combine small particle size, large specific surface area, and basic sites with different strength associated to hydroxyl groups, $\mathrm{O}^{2-}-\mathrm{M}^{\mathrm{n}+}$ acidbase pairs and $\mathrm{O}^{2-}$ anions, ${ }^{6-8,37}$ seems to be appropriate catalyst for the Knoevenagel condensation of arylsulfones and aldehydes. Another interesting feature of these materials is the possibility of tailor their basic properties (density and strength distribution of basic sites) for the process under study, by adjusting their chemical composition (Al/ $(\mathrm{Al}+\mathrm{Mg})$ molar ratio) and/or the method of preparation of the parent hydrotalcite. $7,22,23,37,38$

The use of Mg,Al-mixed oxides derived from hydrotalcites as environmentally friendly catalysts for the synthesis of $\alpha$-phenyl- 
sulfonylcinnamonitrile, at $373 \mathrm{~K}$, was first reported by Climent et al..$^{33}$ The parent hydrotalcites were synthesized at $\mathrm{pH}=13$ and aged at $473 \mathrm{~K}$ for $18 \mathrm{~h}$. They found that the corresponding mixed oxides showed a maximum activity for an $\mathrm{Al} /(\mathrm{Al}+\mathrm{Mg})$ molar ratio of 0.20 . However, they were slightly less active than an ALPON catalysts with 13.9 wt. $\%$ of $\mathrm{N}$ under similar experimental conditions. ${ }^{33}$ The synthesis of unsaturated arylsulfones over solid catalysts such as $\mathrm{Na}_{2} \mathrm{CaP}_{2} \mathrm{O}_{7}$, doped natural phosphate (KF/NP) and $\mathrm{Na}$ /fluoroapatite (fluoroapatite doped with $\mathrm{NaNO}_{3}$ ) was also studied by Zahouily et $a l .^{39-41}$ under mild conditions in the presence of solvent (methanol or ethanol). Results as good as those reported by Climent et al. ${ }^{33}$ were obtained for $\mathrm{KF} / \mathrm{NP}$ and $\mathrm{Na}$ /fluoroapatite when activated by benziltriethylammonioumchloride (BTEAC).

The present work was developed aiming at to evaluate the role played by the basic and the textural properties of the $\mathrm{Mg}, \mathrm{Al}$-mixed oxides obtained by thermal treatment of hydrotalcites with different $\mathrm{Al} /(\mathrm{Al}+\mathrm{Mg})$ molar ratios on their catalytic performance in Knoevenagel condensation between benzaldehyde and phenylsulfonylacetonitrile producing $\alpha$-phenylsulfonylcinnamonitrile without solvent.

\section{EXPERIMENTAL}

\section{Hydrotalcite synthesis and activation}

The hydrotalcites used as catalyst precursors were prepared by coprecipitation at room temperature, as previously described by Noda Pérez et al.. ${ }^{9}$ The synthesis gels were produced by slowly dropping $\left(60 \mathrm{~mL} \mathrm{~h}^{-1}\right)$ solution A $(100 \mathrm{~mL})$, containing $\mathrm{Mg}\left(\mathrm{NO}_{3}\right)_{2} \cdot 6 \mathrm{H}_{2} \mathrm{O}$ and $\mathrm{Al}\left(\mathrm{NO}_{3}\right)_{3} \cdot 9 \mathrm{H}_{2} \mathrm{O}([\mathrm{Al}+\mathrm{Mg}]=1.5 \mathrm{M}$ and $\mathrm{Al} /(\mathrm{Al}+\mathrm{Mg})$ molar ratios equal to $0.20,0.25$ or 0.33$)$ into solution $\mathrm{B}(100 \mathrm{~mL})$, prepared by dissolving appropriate amounts of $\mathrm{Na}_{2} \mathrm{CO}_{3}$ and $\mathrm{NaOH}$ in distilled water in order to obtain $\left[\mathrm{CO}_{3}{ }^{2-}\right]$ equal to $1.0 \mathrm{~mol} / \mathrm{L}$ and a constant $\mathrm{pH}$ during the aging of the gel, under vigorous stirring. The gels were aged under $\mathrm{pH}(10)$ at $333 \mathrm{~K}$ for $18 \mathrm{~h}$ and the solids obtained were filtered and washed with hot distilled water $(363 \mathrm{~K})$ until $\mathrm{pH} 7$. Then they were dried at $353 \mathrm{~K}$ overnight. The hydrotalcites prepared were named as $H T X X$, where $X X$ is the $\mathrm{Al} /(\mathrm{Al}+\mathrm{Mg}$ ) nominal molar ratio (in \%).

To obtain the Mg,Al-mixed oxides the samples were calcined under dry air from room temperature up to $723 \mathrm{~K}_{\text {at }} 1 \mathrm{~K} \mathrm{~min}^{-1}$, and kept at this temperature for $10 \mathrm{~h}$ immediately before each run. The mixed oxides so obtained were named as $M O X X$, where $X X$ is the same as that of the parent hydrotalcite.

\section{Physico-chemical characterization}

The chemical composition of the as-synthesized hydrotalcite samples was determined by atomic absorption spectrometry (AAS) using a Perkin-Elmer AAS 1100B spectrometer. X-ray diffraction patterns (XRD) were recorded in a Rigaku X-Ray Diffractometer equipped with a graphite monochromator using $\mathrm{CuK} \alpha$ radiation, 40 $\mathrm{kV}$ and $40 \mathrm{~mA}$. The software Materials Data Jude, Version 5.0, was employed for structural refinement aiming at calculating the cell parameters. Thermal decomposition of hydrotalcites, evaluated by thermogravimetric analysis (TGA) and derivative thermoanalysis (DTA), was carried out in a Rigaku Thermobalance TAS100 operating under a flow of air at a $10 \mathrm{~K} \mathrm{~min}^{-1}$ heating rate up to $1273 \mathrm{~K}$.

The textural characteristics of the $\mathrm{Mg}$,Al-mixed oxides, such as BET specific area, external area (t-plot method) and pore volume (BJH method), were determined by $\mathrm{N}_{2}$ adsorption-desorption at 77 $\mathrm{K}$ in a Micromeritics ASAP 2000. Prior to the analyses, the samples were outgassed for $3 \mathrm{~h}$ at $723 \mathrm{~K}$. The morphology and the size of the particles of the mixed oxides were obtained by scanning electron microscopy (SEM) in a JEOL-JSM 5800 microscope operating at an accelerating voltage of $20 \mathrm{kV}$. Before the analysis, the samples were mounted in a stub and were sputter-coated with a fine layer of gold.

The relative basicity of the $\mathrm{Mg}, \mathrm{Al}-$ mixed oxides was evaluated by means of the diacetone alcohol (DAA) retroaldolization model reaction that forms acetone as the only product via basic catalysis (Figure 1S, supplementary material). ${ }^{9}$ It was studied in a fixed-bed microreactor at $1 \mathrm{~atm}, 313 \mathrm{~K}$ and WHSV (gram of DAA per hour per gram of catalyst) equal to $19.3 \mathrm{~h}^{-1}$. The reactant was fed to the reactor by bubbling nitrogen $\left(170 \mathrm{~mL} \mathrm{~min}^{-1}\right)$ through a saturator containing DAA held at $303 \mathrm{~K}$. Before the reaction, the original hydrotalcite was calcined in situ under dry air at $723 \mathrm{~K}$ for $10 \mathrm{~h}$ (heating rate of $101 \mathrm{~K} \mathrm{~min}^{-1}$ ). Then, the system was cooled down to $313 \mathrm{~K}$ and the reaction started. The exit stream was regularly analyzed by on-line gas chromatography (50 m CP-Sil 5CB column on a Chrompack 9000 gas chromatograph).

The density and the strength distribution of the basic sites of the calcined hydrotalcites were determined by temperature-programmed desorption (TPD) of $\mathrm{CO}_{2}$. The samples were produced in situ by treating the hydrotalcite precursors as described above. Pure $\mathrm{CO}_{2}$ was adsorbed at room temperature and the sample was flushed with $\mathrm{He}$ to eliminate physically adsorbed molecules. TPD analyses were run under $\mathrm{He}$ at a heating rate of $20 \mathrm{~K} \mathrm{~min}^{-1}$ up to $723 \mathrm{~K}$. The amount of $\mathrm{CO}_{2}$ chemisorbed and its desorption profile were measured on a Micromeritics 2900 TPR/TPD analyzer with a quadrupole mass spectrometer detector (Balzers QMS-200).

\section{Reaction procedure}

The reaction was carried out in liquid phase without solvent under inert atmosphere $\left(\mathrm{N}_{2}\right)$ in a $10 \mathrm{~mL}$ three-necked round bottom glass flask immersed in a thermostated silicone oil bath and equipped with a reflux condenser connected to the central neck (Figure $2 \mathrm{~S}$, supplementary material). After purging the system with $\mathrm{N}_{2}$, benzaldehyde ( 8 mmoles) and phenylsulfonylacetonitrile ( 8 mmoles) were introduced in the reactor and the system was heated to the desired temperature ( 373 or 383 K) under magnetic stirring. Next, the catalyst (obtained by calcination ex-situ under the conditions previously described) was rapidly transferred to the reactor containing the mixture of the reactants and the reaction started. The concentration of catalyst was 1 or $5 \mathrm{wt} . \%$ with respect to the weight of reactants. Samples were periodically taken by means of a filtering syringe, dissolved in acetone and analyzed by gas chromatography using a $30 \mathrm{~m}$ Supelco 2/400, 34, SPB/5 capillary column in a Varian 3300 gas chromatograph (FID). Quantitative determinations were based on the calculated response factors for binary mixtures of the reactants and reaction product. The maximum reaction time explored was $22 \mathrm{~h}$.

\section{RESULTS AND DISCUSSION}

\section{Physico-chemical characterization}

The results of chemical analysis of the hydrotalcite samples, expressed by their $\mathrm{Al} /(\mathrm{Al}+\mathrm{Mg})$ molar ratios, are shown in Table 1 . It can be observed that, for the sample with the largest $\mathrm{Al}$ content, the $\mathrm{Al} /(\mathrm{Al}+\mathrm{Mg})$ molar ratio was slightly lower than that of the corresponding synthesis gel, indicating that the incorporation of $\mathrm{Al}$ from the gel was slightly smaller than that of $\mathrm{Mg}$. Similar trend was also observed by other authors. ${ }^{42,43}$

The X-ray diffractograms of the as-synthesized samples show the characteristic pattern of hydrotalcite in carbonate form (Figure $3 \mathrm{~S}$, supplementary material). The lattice parameters, $a$ and $c$, typical of hydrotalcite structures with rombohedral 3R symmetry were calculated from the X-ray diffractograms (peaks associated to 
Table 1. Chemical analysis, cell parameters and thermogravimetric analysis of synthesized hydrotalcites

\begin{tabular}{|c|c|c|c|c|c|c|c|c|c|}
\hline \multirow[t]{2}{*}{ Sample } & \multicolumn{2}{|c|}{$\mathrm{Al} /(\mathrm{Al}+\mathrm{Mg})$} & \multirow[t]{2}{*}{$a(\AA)$} & \multirow[t]{2}{*}{$c(\AA)$} & \multicolumn{2}{|c|}{$\begin{array}{c}\text { Loss of interlayer } \\
\text { water }\end{array}$} & \multicolumn{2}{|c|}{$\begin{array}{l}\text { Dehydration / } \\
\text { decarbonation }\end{array}$} & \multirow[t]{2}{*}{ Chemical formula } \\
\hline & gel $^{\mathrm{a}}$ & sample & & & (wt.\%) & $\mathrm{T}(\mathrm{K})$ & (wt.\%) & $\mathrm{T}(\mathrm{K})$ & \\
\hline HT20 & 0.20 & 0.20 & $3.063 \pm 0.0004$ & $23.49 \pm 0.021$ & 18.2 & 477 & 26.6 & 670 & $\mathrm{Mg}_{6.4} \mathrm{Al}_{1.6}\left(\mathrm{CO}_{3}\right)_{0.8}(\mathrm{OH})_{16} .6 .4 \mathrm{H}_{2} \mathrm{O}$ \\
\hline HT25 & 0.25 & 0.25 & $3.060 \pm 0.0023$ & $23.32 \pm 0.102$ & 18.8 & 476 & 24.6 & 671 & $\mathrm{Mg}_{6} \mathrm{Al}_{2}\left(\mathrm{CO}_{3}\right)(\mathrm{OH})_{16} .6 .8 \mathrm{H}_{2} \mathrm{O}$ \\
\hline HT33 & 0.33 & 0.31 & $3.047 \pm 0.006$ & $22.91 \pm 0.064$ & 18.7 & 494 & 24.5 & 676 & $\mathrm{Mg}_{5.5} \mathrm{Al}_{2.5}\left(\mathrm{CO}_{3}\right)_{1.25}(\mathrm{OH})_{16} .7 .0 \mathrm{H}_{2} \mathrm{O}$ \\
\hline
\end{tabular}

a: Nominal value. ${ }^{\text {b: Experimental value }}$

planes (003), (006), (110) and (113)) and are also shown in Table 1. The values of parameter $a$, which is a function of the cation-cation distance in the hydroxide layers, were in the range 3.14-3.04 $\AA$ and they decreased with increasing $\mathrm{Al} /(\mathrm{Al}+\mathrm{Mg})$ molar ratio due to the progressive isomorphic replacement of $\mathrm{Mg}^{2+}$ (ionic radii of $0.65 \AA$ ) by $\mathrm{Al}^{3+}$ (ionic radii of $0.50 \AA$ ). Parameter $c$, which is related to the layer thickness (brucite-like sheet plus an interlayer), is influenced both by the size of the interlayer anion and the $\mathrm{M}^{2+}-\mathrm{M}^{3+}$ cations. It also decreased with the increase in the $\mathrm{Al}$ content. ${ }^{2}$

The TGA/DTA results for the as-synthesized samples are comparatively reported in Table 1 . They show that the maximum temperature of the peaks in the DTA profiles slightly increases with increasing aluminum content. Two well-defined weight losses were observed in the profiles (Figure $4 \mathrm{~S}$, supplementary material), which are in good agreement with those reported in the literature for hydrotalcites in carbonate form. ${ }^{1,3,4}$ The first step, up to $500 \mathrm{~K}$, corresponds to the loss of interlayer water, while the second step, between 548 and $723 \mathrm{~K}$, is associated to dehydroxylation and decarbonation.

From the chemical analysis $(\mathrm{Al} /(\mathrm{Al}+\mathrm{Mg})$ molar ratio) and the TGA results (weight loss associated to interlayer water) the chemical formula of the hydrotalcite samples were calculated and are also presented in Table 1.

Upon calcination at $723 \mathrm{~K}$ the layered structure of hydrotalcites collapsed, forming the $\mathrm{Mg}$,Al-mixed oxides with a poorly crystallized $\mathrm{MgO}$ periclase-type structure whose unit cell parameter decreases as the $(\mathrm{Al} /(\mathrm{Al}+\mathrm{Mg}))$ molar ratio increases. Inspection of the corresponding $\mathrm{N}_{2}$ adsorption/desorption isotherms indicated that all samples presented IUPAC type IV isotherms (Figure 5S, supplementary material), confirming that the thermal decomposition of the hydrotalcite samples produced mesoporous Mg,Al-mixed oxides (Figure 6S, supplementary material). Their main textural characteristics are shown in Table 2 and they indicate that the BET areas decrease with increasing $\mathrm{Al}$ content and the mesoporous (diameter up to $60 \mathrm{~nm}$ ) volume, calculated by the $\mathrm{BJH}$ method using the adsorption branch, present a minimum value (close to $0.40 \mathrm{~cm}^{3} / \mathrm{g}$ ) for the sample with an $\mathrm{Al} /(\mathrm{Al}+\mathrm{Mg}$ ) ratio equal to 0.25 . Microporous volumes are not very significant, although they contribute in an important way to the BET area, and the external area actually reflects the contribution of the mesoporous system.

The scanning electron micrographs of the mixed oxides indicated that they are formed by particles with irregular surface and without a well-defined shape, as shown in Figure 1, for samples MO20 and

Table 2. Textural and morphological characteristics of calcined hydrotalcites

\begin{tabular}{lcccc}
\hline Sample & $\begin{array}{c}\mathrm{S}_{\text {BET }} \\
\left(\mathrm{m}^{2} / \mathrm{g}\right)\end{array}$ & $\begin{array}{c}\mathrm{S}_{\text {EXT }} \\
\left(\mathrm{m}^{2} / \mathrm{g}\right)^{\mathrm{a}}\end{array}$ & $\begin{array}{c}\mathrm{V}_{\text {micro }} \\
\left(\mathrm{cm}^{3} / \mathrm{g}\right)^{\mathrm{a}}\end{array}$ & $\begin{array}{c}\mathrm{V}_{\text {meso }} \\
\left(\mathrm{cm}^{3} / \mathrm{g}\right)^{\mathrm{b}}\end{array}$ \\
\hline MO20 & 271 & 179 & 0.041 & 0.47 \\
MO25 & 242 & 131 & 0.048 & 0.37 \\
MO33 & 179 & 118 & 0.027 & 0.54 \\
\hline
\end{tabular}

${ }^{\mathrm{a}}$ t-plot. ${ }^{\mathrm{b}} \mathrm{BJH}$ adsorption branch
MO25, and in Figure 7S - supplementary material, for sample MO33. It can be observed that the $\mathrm{Al}$ content influenced the size and the morphology of the particles. Thus, the sample with the lowest Al content (MO20) was formed by aggregates of small particles with size in the range $4-10 \mu \mathrm{m}$ while sample MO25 was formed by big particles in the range $400-700 \mu \mathrm{m}$ and sample MO33 by particles of about $70 \mu \mathrm{m}$ and aggregates of small particles with size of 5-10 $\mu \mathrm{m}$.

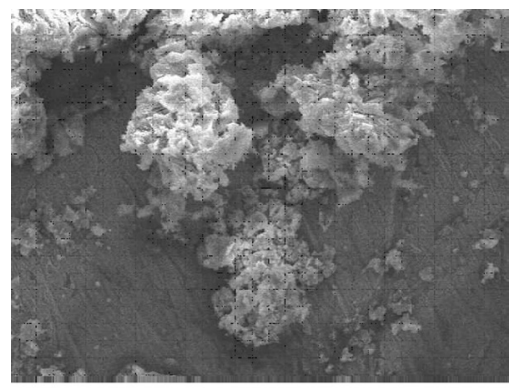

(a)

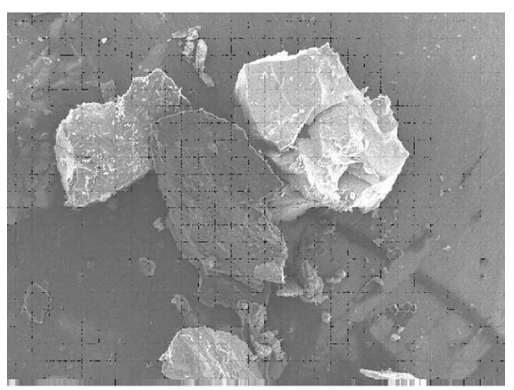

(b)

Figure 1. SEM micrographs of Mg,Al-mixed oxide derived from: (a) HT20 (magnification 450X, photo width $293 \mu \mathrm{m}$ ); (b) HT25 (magnification 70X, photo width $1.89 \mathrm{~mm}$ )

\section{Basicity characterization}

Figure 2 shows the molar fraction of acetone formed during the retroaldolization of diacetone alcohol catalyzed by the $\mathrm{Mg}, \mathrm{Al}$-mixed oxides. It can be observed that the initial activity of the samples (given by the acetone molar fraction) decreased with the increasing $\mathrm{Al}$ content up to $\mathrm{Al} /(\mathrm{Al}+\mathrm{Mg})$ molar ratio equal to 0.25 . For samples MO25 and MO33 the behavior was similar. This seems to support previous observations of other authors ${ }^{1,44}$ that, although the basic sites density decreases with increasing $\mathrm{Al}$ content, the relative proportion of strongly basic sites increases. Although this possibility can not be discarded, one would expect it to hold for demanding reactions and this is not the case of the diacetone alcohol retroaldolization reaction, which can be easily performed even at room temperature.

On the other hand, Figure 3 indicates that a good correlation is observed between acetone initial molar fraction and external area for all the mixed oxide samples. This suggests that for a facile reaction such as the 
present one accessibility of the reactant to the active sites on the surface of the mesopores and on the external surface of the particles (as expressed by $\mathrm{S}_{\mathrm{ext}}$ ) is the governing parameter rather than the strength of the sites or their theoretical global concentration (related to the $\mathrm{Al}$ content).

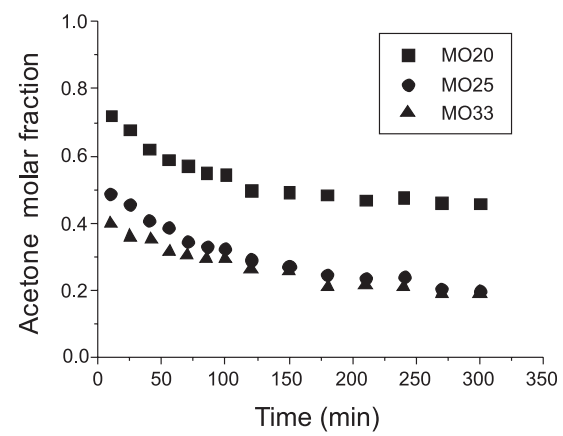

Figure 2. Acetone formation from retroaldolization of DAA (atmospheric pressure, $313 \mathrm{~K}, \mathrm{WHSV}=19.3 \mathrm{~h}^{-1}$ )

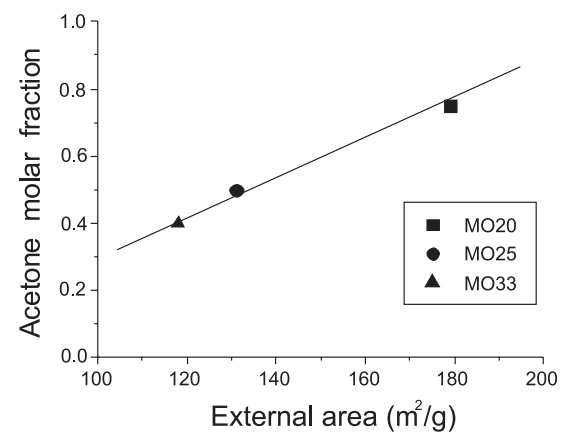

Figure 3. Relation between initial activity for retroaldolization of DAA and external area

The thermograms corresponding to $\mathrm{CO}_{2}$ temperature-programmed desorption are shown in Figure 4. They were deconvoluted into three desorption peaks with maxima in the ranges 390-411, 430-461, and $510-550 \mathrm{~K}$. Deconvoluting into three peaks gave the best fit and agrees with previous results of Di Cosimo et al. ${ }^{36}$ that associated their results to those obtained from the infrared spectra of adsorbed $\mathrm{CO}_{2}$ and related the L.T.P. (low-strength basic sites) to surface hydroxyl groups and the M.T.P. (medium-strength basic sites) and H.T.P. (highstrength basic sites) to surface basic oxygen atoms.

The basic sites density, shown in Table 3, followed the order MO20 $>\mathrm{MO} 25 \approx \mathrm{MO} 33$, which is similar to that observed for the activity of the samples for DAA retroaldolization. Table 3 also shows the relative contribution of each individual desorption peak calculated by the integration of its profile. It can be observed that for the Mg,Al-mixed oxides the high strength basic sites are predominant, as previously reported by Veloso et al. ${ }^{20}$ and the relative amount of sites with different strengths is influenced by the $\mathrm{Al}$ content. These results did not support the suggestion ${ }^{1,44}$ that the increase in $\mathrm{Al}$ content decreases the basic sites density but increases the relative proportion of strong basic sites.

\section{Catalytic tests}

The scheme of the base-catalyzed Knoevenagel condensation between phenylsulfonylacetonitrile (1) and benzaldehyde (2) producing $\alpha$-phenylsulfonylcinnamonitrile (4) is represented in Figure 5. The mechanism generally accepted for the reaction involves, in the first step, the abstraction of a proton from phenylsulfonylacetonitrile (1) by a basic site with the formation of the corresponding carbanion (1). This carbanion ( $\left.1^{\prime}\right)$ attacks the carbonyl group of the benzaldehyde (2), giving

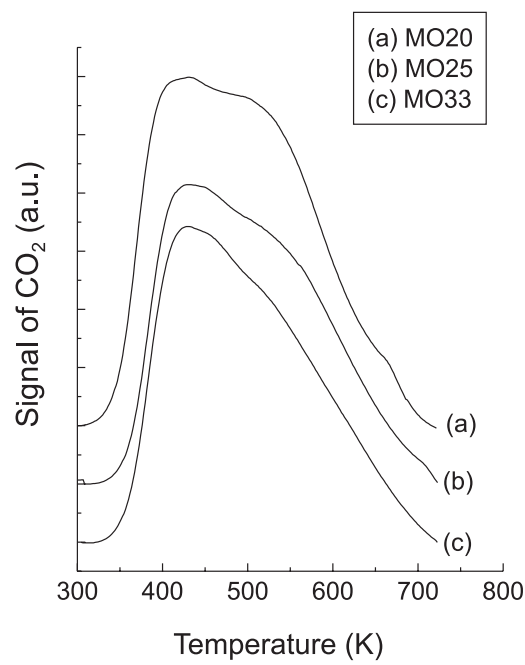

Figure 4. Profiles of temperature programmed desorption of $\mathrm{CO}_{2}$

Table 3. Results of temperature-programmed desorption of $\mathrm{CO}_{2}$ for the studied samples

\begin{tabular}{lllll}
\hline & $\begin{array}{l}\text { Basic site } \\
\text { densities } \\
\text { Catalyst }\end{array}$ & \multicolumn{4}{l}{ Desorption peaks (area \%) } \\
& $\begin{array}{l}(\mu \mathrm{mol} \mathrm{de} \\
\left.\mathrm{CO}_{2} / \mathrm{g}\right)\end{array}$ & $\begin{array}{l}\text { L.T.P. } \\
\text { 390-411 K }\end{array}$ & $\begin{array}{l}\text { M.T.P. } \\
\text { 430-461 K }\end{array}$ & $\begin{array}{l}\text { H.T.P. }^{\mathrm{c}} \\
510-550 \mathrm{~K}\end{array}$ \\
\hline MO20 & 502 & 18 & 35 & 47 \\
MO25 & 412 & 16 & 23 & 61 \\
MO33 & 410 & 17 & 28 & 55 \\
\hline
\end{tabular}

${ }^{\mathrm{a}}$ L. T. P. $=$ low temperature peak $;{ }^{\mathrm{b}}$ M.T.P. $=$ medium (intermediate) temperature peak $;{ }^{\mathrm{c}}$ H.T.P. $=$ high temperature peak<smiles>CCC(C#N)[Hg]O[Sb]</smiles>

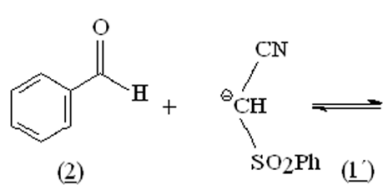<smiles>N#CC(O[GaH])C([O-])c1ccccc1</smiles><smiles>C=CC(=O)c1cccc(C=C)c1O</smiles>

(3)<smiles>N#C/C(=C/c1ccccc1)[Se]O</smiles>

(4)

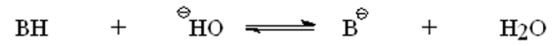

Figure 5. Mechanism of Knoevenagel condensation between benzaldehyde and phenylsulfonylacetonitrile

the alcohol intermediate ( $\underline{3})$. In the last step, water is removed and a $\mathrm{C}=$ $\mathrm{C}$ bond is formed. Finally, the active site of the basic catalyst is restored.

The comparison of the catalytic performance of the different mixed oxides was initially carried out at $373 \mathrm{~K}$, using $1 \mathrm{wt} . \%$ of catalyst. The effect of reaction time on conversion of phenylsulfonylacetonitrile is presented in Figure 6. It can be observed that $\mathrm{Mg}$,Al-mixed oxides are active in catalyzing the desired reaction, the highest activity being presented by the catalyst with the lowest aluminum content (MO20), 
as also observed by Climent et $a .^{33} \alpha$-phenylsulfonylacetonitrile conversion decreased with increasing $\mathrm{Al} /(\mathrm{Al}+\mathrm{Mg})$ ratios, passing through a minimum for $\mathrm{Al} /(\mathrm{Al}+\mathrm{Mg})$ equal to 0.25 , and then slightly increasing. This behavior is different from that reported by Climent et al. ${ }^{33}$ who observed a decreasing activity when the $\mathrm{Al} /(\mathrm{Al}+\mathrm{Mg})$ ratio was increased above 0.20 . For all the studied catalysts, the selectivity to $\alpha$-phenylsulfonylcinnamonitrile was $100 \%$.

For the studied samples, increasing the $\mathrm{Al}$ content from $\mathrm{Al} /(\mathrm{Al}$ $+\mathrm{Mg}$ ) $=0.20$ to 0.25 decreases both the relative basicity (measured by DAA retroaldolization) and the basic sites density (TPD of $\mathrm{CO}_{2}$ ). Further increase in $\mathrm{Al}$ content to 0.33 did not change these basic characteristics significantly. Thus, relative basicity and basic sites density explain the best performance of catalyst MO20 for the Knoevenagel condensation between phenylsulfonylacetonitrile and benzaldehyde. Besides these basic characteristics, the textural properties (external and BET specific areas) could also justify the highest activity of sample MO20. However, to explain the order of catalytic activity observed: MO20 >> MO33 > MO25, it is important to consider also the relative amount of sites with different basic strength.

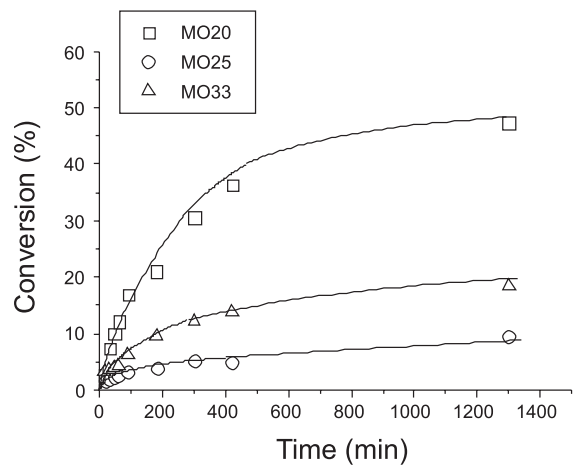

Figure 6. Effect of reaction time on conversion of phenylsulfonylacetonitrile (373 K, atmospheric pressure, phenylsulfonilacetonitrile/benzaldehyde $=1$ (molar), 1 wt.\% of catalyst)

For the reaction under study, basic sites with weak to intermediate strength should be able to perform the reaction since in the phenylsulfonylacetonitrile molecule the methylenic group is strongly activated by the cyano and phenylsulfonyl groups, making it relatively easy for the catalyst to generate the carbanium by extracting the proton. Indeed, this is the case of the catalytic activity (given by phenylsulfonylacetonitrile conversion) presented in Figure 6 that follow the same trend of the relative amount of weak plus intermediate strength basic sites of the samples (Table 3).

It is important to notice that the particle size could also play an important role since the reaction involves voluminous molecules and the existence of diffusion limitations associated to large particles should affect the catalytic performance, since they can restrict the access of the reactant to the active sites inside the pores. This suggestion is supported by the fact that the catalytic activity of the samples: MO20 >> MO33 > MO25 followed an order inverse as to their crystallite sizes $(\mathrm{MO} 20<\mathrm{MO} 33<\mathrm{MO} 25)$.

The role of basic, textural and morphological properties was also observed when the studied samples (MO20, MO25 and MO33) were evaluated as catalysts on the aldol condensation of citral and acetone forming pseudoionones. ${ }^{9}$ The results were summarized in Table 4, which shows that the highest activity was presented by the catalyst with the lower aluminum content (MO20). Citral conversion decreased with the increase in $\mathrm{Al} /(\mathrm{Al}+\mathrm{Mg})$ ratio up to 0.25 and increased for the sample with the highest Al content. Again, relative basicity, basic sites density and textural characteristics explain the best catalytic performance of MO20 whereas the relative distribution of basic sites with different strength must be considered to justify the order of catalytic activity (MO20 > MO33 > MO25). Since this reaction also involves voluminous molecules, diffusion limitations associated the differences on crystallite size can also be taken into account.

Table 4. Citral conversion as a function of $\mathrm{Al} /(\mathrm{Al}+\mathrm{Mg})$ molar ratio $(398 \mathrm{~K}$, autogenous pressure, acetone/citral $=1$ (molar), $5 \%$ of catalyst $)$

\begin{tabular}{lc}
\hline Catalyst & Citral conversion $(\%)$ \\
\hline MO20 & 56.0 \\
MO25 & 32.4 \\
MO33 & 43.5 \\
\hline
\end{tabular}

By increasing the reaction temperature to $383 \mathrm{~K}$ and the catalyst concentration to $5 \mathrm{wt}$.\% a near complete conversion of phenylsulfonylacetonitrile is reached after only $45 \mathrm{~min}$ of reaction with $100 \%$ selectivity to the desired product (Figure $8 \mathrm{~S}$, supplementary material). Table 5 shows the results obtained in the present work with MO20 as catalyst along with those reported in the literature for the same reaction over other catalysts. Although the reaction yields cannot be directly compared since the reactions were carried out under different experimental conditions (temperature, catalyst concentration and presence/absence of solvent), it can be observed that our best result is equivalent to the best ones reported over other solid catalysts. Thus, this confirms the $\mathrm{Mg}$,Al-mixed oxides derived from hydrotalcites as potential catalysts for clean processes involving Knoevenagel condensation and other base-catalyzed reactions with interest in fine chemistry.

\section{CONCLUSIONS}

The chemical composition of the parent hydrotalcites matched that of the synthesis gels. Their lattice parameters, calculated from the $\mathrm{X}$-ray diffractograms, decreased with the increase in the $\mathrm{Al} /(\mathrm{Al}+\mathrm{Mg})$ molar ratio due the partial replacement of $\mathrm{Mg}^{2+}$ cations by the smaller $\mathrm{Al}^{3+}$ cations. As expected, the TGA/DTA profiles showed two welldefined weight losses and the increase in the aluminum content shifted the peaks in DTA profiles for slightly higher temperatures.

Textural characterization of the Mg,Al-mixed oxides showed that the BET area decreased with increasing aluminum content, that mesoporous volumes were minima for samples with $\mathrm{Al} /(\mathrm{Al}+\mathrm{Mg})$ ratio equal to 0.25 , that microporous volumes were not very significant, and that the external areas reflect the contribution of the mesoporous.

The scanning electron micrographs of the mixed oxides indicated that they are formed by aggregates of particles with irregular surface and without a well-defined shape whose sizes were influenced by their chemical composition.

The relative basicity of the mixed oxides, determined by retroaldolization of diacetone alcohol, decreased with the increase in $\mathrm{Al}$ content up to $\mathrm{Al} /(\mathrm{Al}+\mathrm{Mg})$ molar ratio equal to 0.25 . Further increase in the $\mathrm{Al}$ content did not influence this basic property. On the other hand, a good correlation was observed between the relative basicity and external area, suggesting that for this model reaction accessibility of the reactant to the active sites is the governing parameter rather than the strength of the sites or their theoretical global concentration (related to the $\mathrm{Al}$ content). The basic sites density determined by TPD of $\mathrm{CO}_{2}$ followed the same order of the relative basicity (MO20 $>\mathrm{MO} 25 \approx \mathrm{MO} 33$ ). It was also observed that the high strength basic sites are predominant and that the relative amount of sites with different strengths is influenced by the $\mathrm{Al}$ content.

The Mg,Al-mixed oxides derived from hydrotalcites were efficient catalysts for the Knoevenagel reaction between benzaldehyde 
Table 5. Knoevenagel condensation between benzaldehyde and phenylsulfonylacetonitrile. $\alpha$-phenylsulfonylcinnamonitrile yields over different solid catalysts

\begin{tabular}{|c|c|c|}
\hline Solid Catalyst & $\begin{array}{l}\text { Yield (time) } \\
{[(\%)(\text { time/h)] }}\end{array}$ & Reference \\
\hline MO20 & $50(22)^{\mathrm{a}}$ & This work \\
\hline MO20 & $100(3)^{b}$ & This work \\
\hline Na/FAP/BTEAC & $96(4)$ & Zahouily et al. ${ }^{40}$ \\
\hline FAP & $78(48)$ & Zahouily et al. ${ }^{40}$ \\
\hline KF/NP/BTEAC & $91(1)$ & Zahouily et al. ${ }^{41}$ \\
\hline $\mathrm{KF} / \mathrm{NP}$ & $60(1)$ & Zahouily et al. ${ }^{41}$ \\
\hline NP/BTEAC & $75(5)$ & Zahouily et al. ${ }^{41}$ \\
\hline $\mathrm{Na}_{2} \mathrm{CaP}_{2} \mathrm{O}_{7} /$ water & $74(1)$ & Zahouily et al. ${ }^{39}$ \\
\hline CsX zeolite & $35(2)$ & Climent et al. ${ }^{38}$ \\
\hline $\mathrm{MgO}$ & $86(2)$ & Climent et a.l ${ }^{38}$ \\
\hline MgAl-mixed oxide & $71(2)$ & Climent et a.l ${ }^{38}$ \\
\hline ALPON $^{d}$ & $95(2)$ & Climent et a.l ${ }^{38}$ \\
\hline
\end{tabular}

a $373 \mathrm{~K} ; 1$ wt. $\%$ of catalyst; ${ }^{\text {b }} 383 \mathrm{~K}, 5$ wt. $\%$ of catalyst ${ }^{\text {c }} \mathrm{Al} /(\mathrm{Al}+\mathrm{Mg})$ molar ratio $=0.25^{\mathrm{d}}$ Atomic ratio $\mathrm{Al}: \mathrm{P}: \mathrm{N}=1: 0.95: 0.42$

and phenylsulfonylacetonitrile producing $\alpha$-phenylsulfonylcinnamonitrile with $100 \%$ selectivity at $373 \mathrm{~K}$. The best catalytic performance was presented by the $\mathrm{Mg}, \mathrm{Al}$-mixed oxide with the lowest aluminum content $(\mathrm{Al} /(\mathrm{Al}+\mathrm{Mg})=0.20)$, that had the highest basic sites density and external area and the smallest particle size. It was proposed that the studied reaction is catalyzed by basic sites with weak to intermediate strength. So, the relative amount of these sites played an important role on catalytic performance.

Since the studied reaction involves voluminous reactants and the catalytic activity also followed an inverse trend as to the particle sizes, the effect of this parameter on the accessibility of the voluminous molecules and consequently on catalytic activity cannot be disregarded.

\section{SUPPLEMENTARY MATERIAL}

Figures identified as $\mathrm{S}$ along the manuscript can be freely accessed as supplementary material (pdf file) in http://quimicanova.sbq.org.br.

\section{ACKNOWLEDGEMENTS}

The authors would like to thank CYTED - Programa Iberoamericano de Ciencia y Tecnología para el Desarrollo (Project V.5), FAPERJ - Fundação de Amparo à Pesquisa do Estado do Rio de Janeiro, and UERJ (PROCIENCIA Program) for the financial support. The cooperation of Prof. A. Corma, director of the Instituto de Tecnologia Química (UPV-CSIC, Valencia, Spain), where the experiments were performed, is also acknowledged.

\section{REFERENCES}

1. Tichit, D.; Lhouty, M. H.; Alain, G.; Chiche, B. H.; Figueras, F.; Auroux, A.; Bartalini, D.; Garrone, E.; J. Catal. 1995, 151, 50.

2. Cavani, F.; Triffirò, F.; Vaccari; A.; Catal. Today 1991, 11, 173.

3. McKenzie, A. L.; Fishel, C. T.; Davis, R. J.; J. Catal. 1992, 138, 547.

4. Rey, F.; Fornés, V.; Rojo, J. M.; J. Chem. Soc. Faraday Trans. 1992, 88, 2233.

5. Del Arco, M.; Martin, C.; Martin, I.; Rives, V.; Trujillano, R.; Spectrochim. Acta 1993, 49A, 1575.

6. Corma, A.; Iborra, S.; Primo, J.; Rey, F.; Appl. Catal., A 1994, 114, 215.

7. Climent, M. J.; Corma, A.; Iborra, S.; Primo J.; J. Catal. 1995, 151, 60.
8. Climent, M.J.; Corma, A.; Iborra, S.; Epping, K.; Velty, A.; J. Catal. 2004, 225, 316.

9. Noda Pérez, C.; Pérez, C. A.; Henriques, C. A.; Monteiro, J. L. F.; Appl. Catal., A 2004, 272, 229

10. Suzuki, E.; Ono, Y.; Bull. Chem. Soc. Jpn. 1988, 61, 1008

11. Corma, A.; Martin-Aranda, R. M.; Appl. Catal., A 1993, 105, 271.

12. Guida, A.; Lhouty, M. H.; Tichit, D.; Figueras, F.; Geneste, P.; Appl. Catal., A 1997, 164, 251

13. Rao, K. K.; Gravelle, M.; Valente, J. S.; Figueras, F.; J. Catal. 1998, 173, 115.

14. Noda Pérez, C.; Alt, G. P.; Werneck, R. M.; Henriques C. A.; Monteiro, J. L. F.; Brazil. J. Chem. Eng. 1998, 15, 120.

15. Roelofs, J. C. A. A.; van Dillen, J. A.; de Jong, P. K.; Catal. Today 2000, 60, 297.

16. Roelofs, J. C. A. A.; van Dillen, J. A.; de Jong, P. K.; Catal. Lett. 2001, $74,91$.

17. Veloso, C. O.; Henriques, C. A.; Dias, A. G.; Monteiro, J. L. F.; Catal. Today 2005, 107-108, 294

18. Angelescu, E.; Pavel, O. D.; Bîrjega, R.; Zavoianu, R.; Constentin, G.; Che, M.; Appl. Catal., A 2006, 308, 13.

19. Abello, S.; Vijaya-Shankar, D.; Pérez-Ramírez, J.; Appl. Catal., A 2008 , 342,119 .

20. Veloso, C. O.; Noda Pérez, C.; Souza, B. M.; Lima, E. C.; Dias, A. G.; Monteiro, J. L. F.; Henriques, C. A.; Microporous Mesoporous Mater. 2008, 107, 23.

21. Choudary, B. M.; Lantam, M. L.; Reddy, C. R. V.; Rao, K. K.; Figueras, F.; J. Mol. Catal. A: Chem. 1999,146, 279.

22. Sharper, H.; Berg-Slot, J. J.; Stork, W. H. J.; Appl. Catal. 1989, 54, 79.

23. Velu, S.; Swamy, C. S.; Appl. Catal., A 1994, 119, 241.

24. Cativela, C.; Figueras, F.; Garcia, J. J.; Mayoral, J. M.; Zumbano, M. M.; Synth. Commun. 1995, 25, 1745

25. Cativela, C.; Figueras, F.; Fraille, J. M.; Garcia, J. J.; Mayoral, J. M.; Tetrahedron Lett. 1995, 36, 4125.

26. Magnus, P. D.; Tetrahedron 1977, 33, 2019.

27. Trost, B. M.; Bull. Chem. Soc. Jpn. 1988, 61, 107.

28. Orita, A.; Yoshioka, N.; Oteru, J.; Chem. Lett. 1997, 26, 1023.

29. Rayner, C. M.; Contemp. Org. Synth. 1995, 2, 409.

30. Zhang, Z.; Liu, G. J.; Wang, Y. L.; Wang, W.; Synth. Commun. 1989, 19, 1167.

31. Trost, B. M.; Schmuff, N. R.; Miller, M. J.; J. Am. Chem. Soc. 1980, 102, 5979 .

32. Orr, D.; Synthesis 1979, 139.

33. Climent, M. J.; Corma, A.; Guil-Lopez, R.; Iborra, S.; Primo, J.; Catal. Lett. 1999, 59, 33.

34. Kondo, K.; Tunemoto, D.; Tetrahedron Lett. 1975, 1007.

35. Olson, G. L.; Cheung, H. O.; Morgan, K. D.; Neukom, C.; Saucy, G.; J. Org. Chem. 1976, 41, 3287.

36. Trost, B.; Verhoeven, T. R.; J. Am. Chem. Soc. 1978, 100, 3435.

37. Di Cosimo, J. I.; Díez, V. K.; Xu, M.; Iglesias, E.; Apestegía, C. R.; J. Catal. 1998, 178, 499 .

38. Corma, A.; Fornés, V.; Rey, F.; J. Catal. 1994, 148, 205.

39. Zahouily, M.; Salah, M.; Bennazha, J.; Rayadh, A.; Sebti, S.; Tetrahedron Lett. 2003, 44, 3255.

40. Zahouily, M.; Salah, M.; Bahlaouan, B.; Mounir, B.; Rayadh, A.; Sebti, S.; Catal. Lett. 2004, 96, 57.

41. Zahouily, M.; Salah, M.; Bahlaouane, B.; Rayadh, A.; Houmam, A.; Hamed, E. A.; Sebti, S.; Tetrahedron 2004, 60, 1631.

42. Roelofs, J. C. A. A.; Lensveld, D. J.; van Dillen, J. A.; de Jong, P. K; J. Catal. 2001, 202, 184.

43. Vucelic, M; Moggridge, C. D.; Jones, W.; J. Phys. Chem. 1995, 99 , 8328.

44. Nakatsuka, T.; Kawasaki, H.; Yamashita, S.; Kohijiya, S.; Bull. Chem. Soc. Jpn. 1979, 52, 2449 


\section{INFLUENCE OF BASIC PROPERTIES OF Mg,AI-MIXED OXIDES ON THEIR CATALYTIC ACTIVITY IN KNOEVENAGEL CONDENSATION BETWEEN BENZALDEHYDE AND PHENYLSULFONYLACETONITRILE}

\section{Caridad Noda Pérez}

Universidade Estadual de Goiás, BR 153 km 98, 75001-970 Anápolis - GO, Brasil

José Luiz Fontes Monteiro

COPPE, Universidade Federal do Rio de Janeiro, CP 68502, 21941-972 Rio de Janeiro - RJ, Brasil

Jose Manoel López Nieto

Instituto de Tecnología Química, Universidad Politécnica de Valencia, Avenida. los Naranjos s/n, 46022 Valencia, Espanha

Cristiane Assumpção Henriques*

Instituto de Química, Universidade do Estado do Rio de Janeiro, Rua São Francisco Xavier, 524, 20550-900 Rio de Janeiro - RJ, Brasil

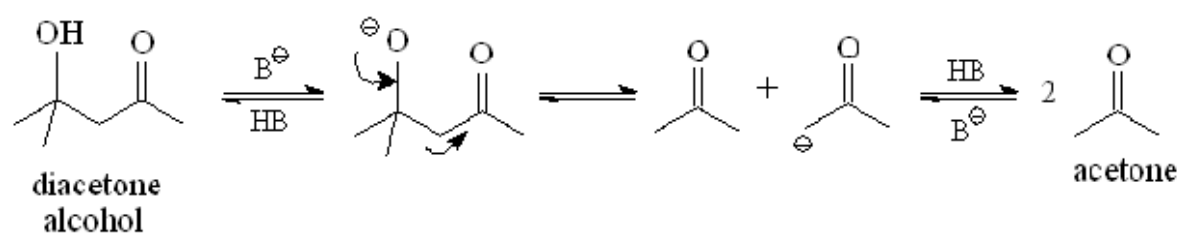

Figure 1S. Reaction scheme of diacetone alcohol retroaldolization

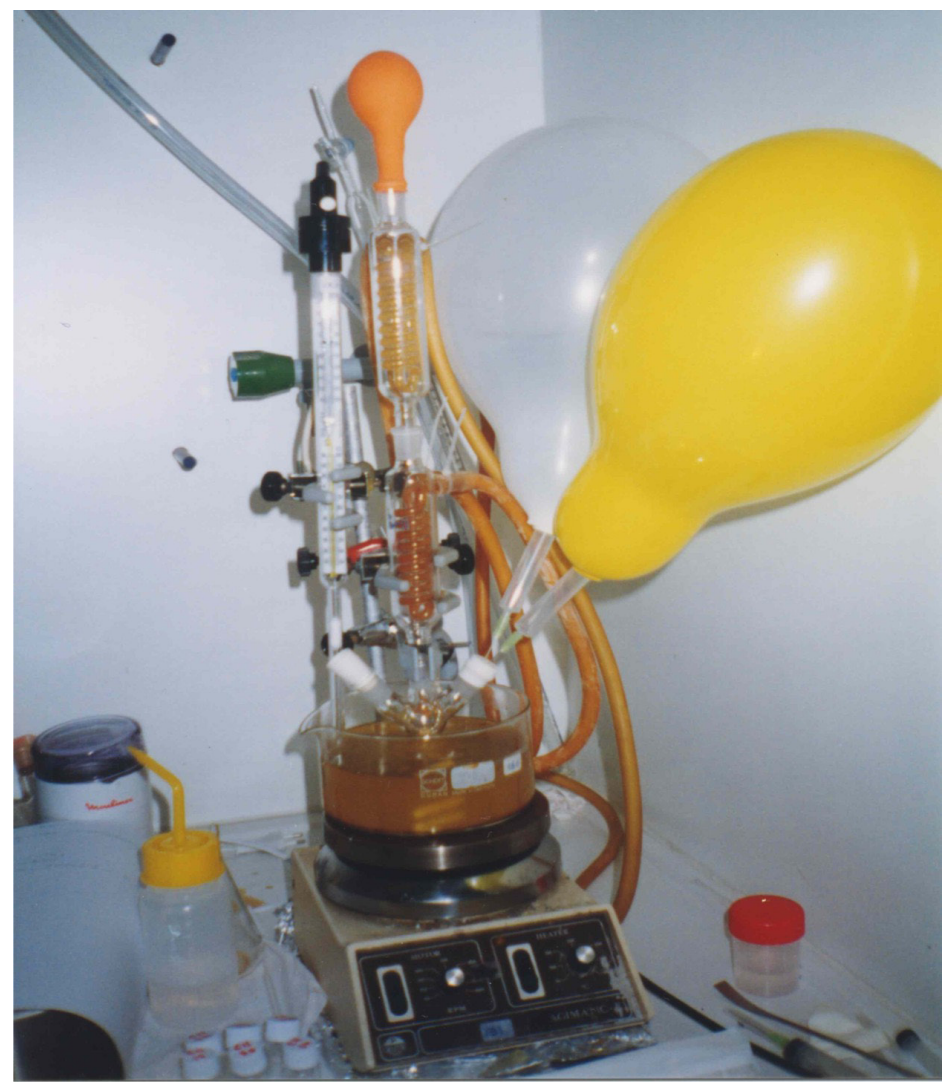

Figure 2S. Reaction system 


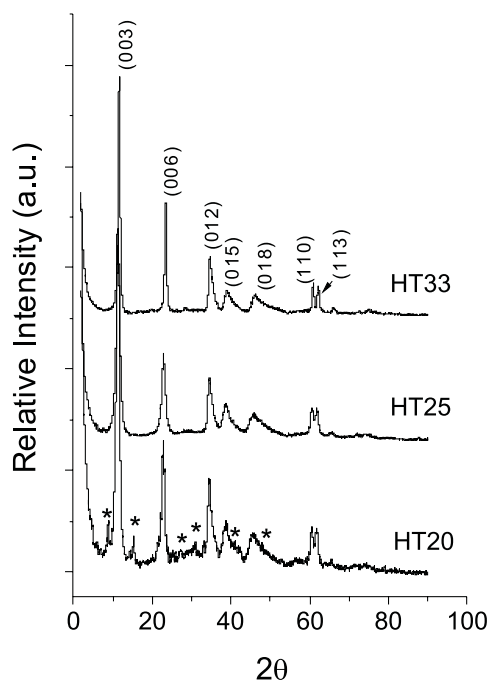

Figure 3S. X-ray diffractograms for the as-synthesized hydrotalcite samples. Peaks marked with (*) correspond to hydromagnesite
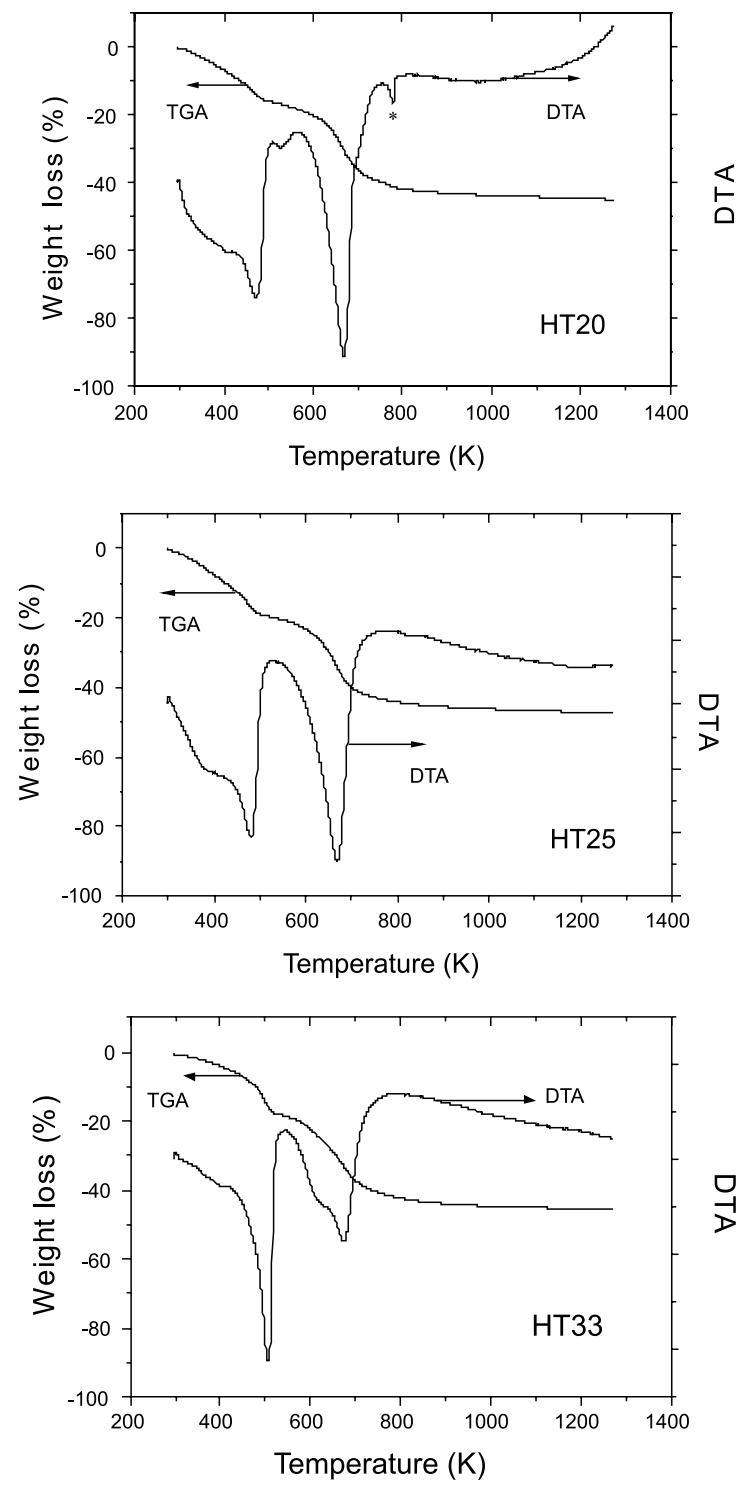

Figure 4S. DTA-TGA profiles for samples HT2O, HT25 and HT33

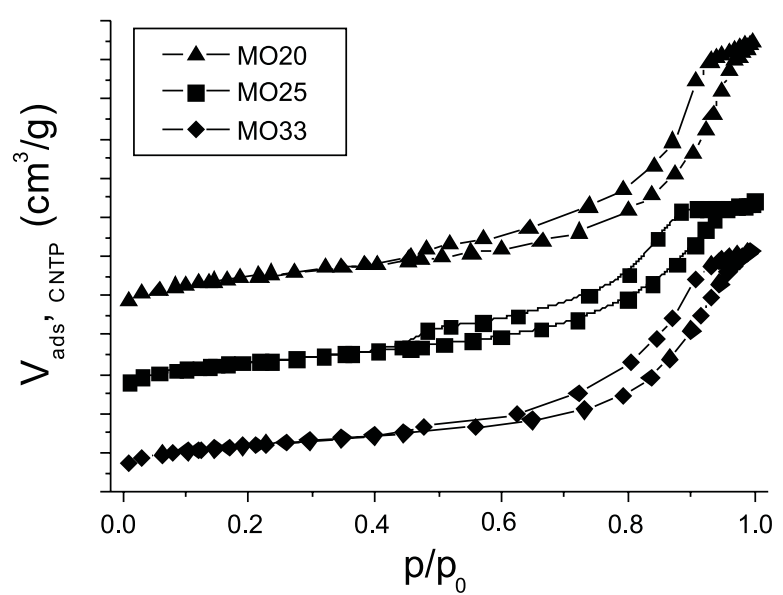

Figure 5S. $\mathrm{N}_{2}$ physisorption isotherms for samples MO20, MO25 and MO33

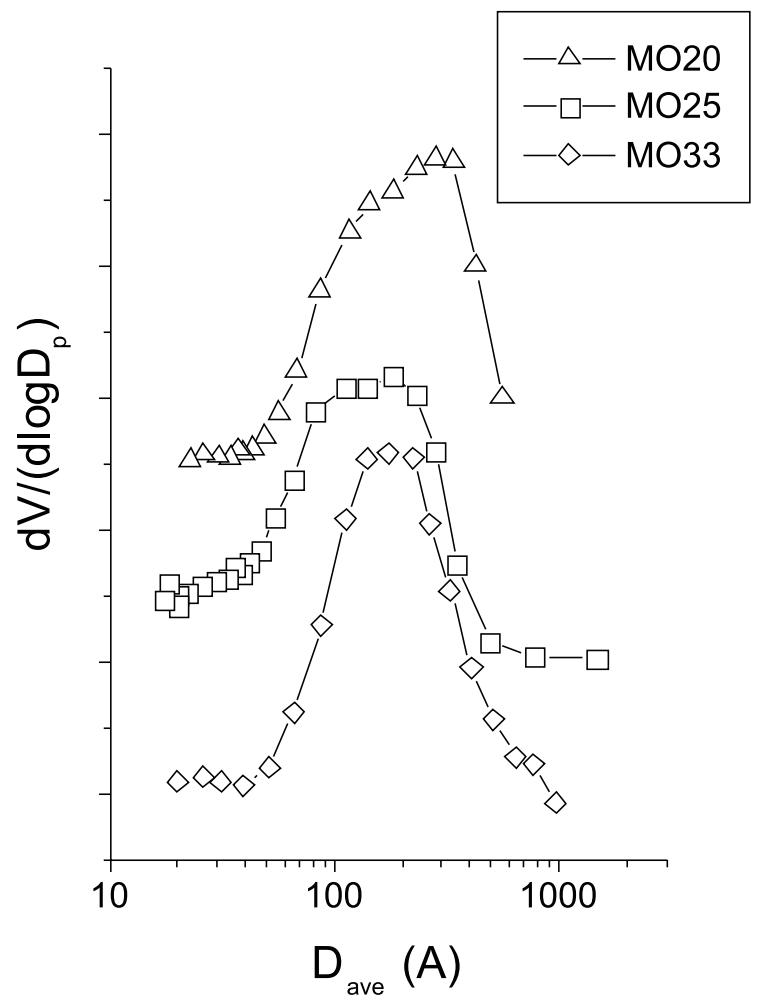

Figure 6S. Pore size distribution for samples MO20, MO25 and MO33 (BJH method, adsorption branch) 


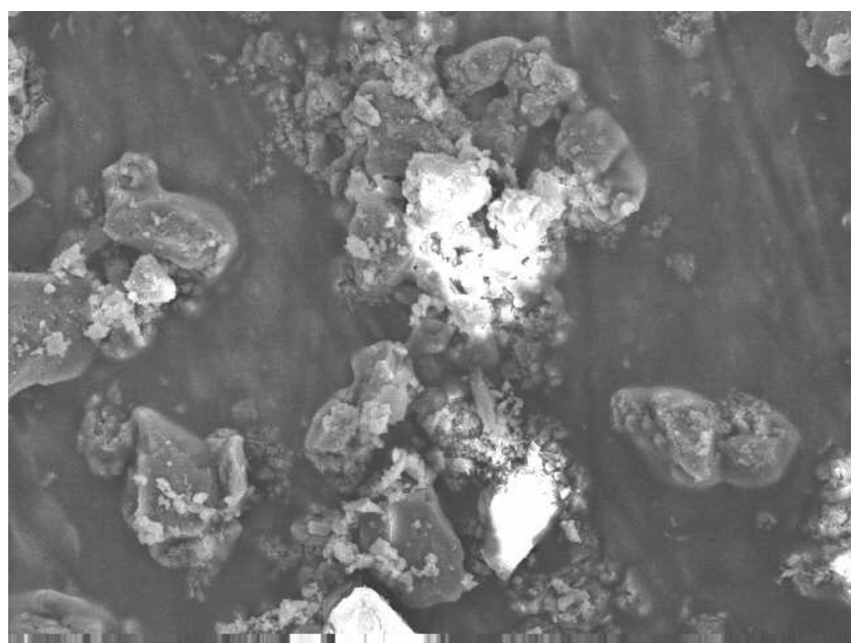

Figure 7S. SEM micrographs of Mg,Al-mixed oxide derived from HT33 (magnification 230X, photo width $574 \mu \mathrm{m}$ )

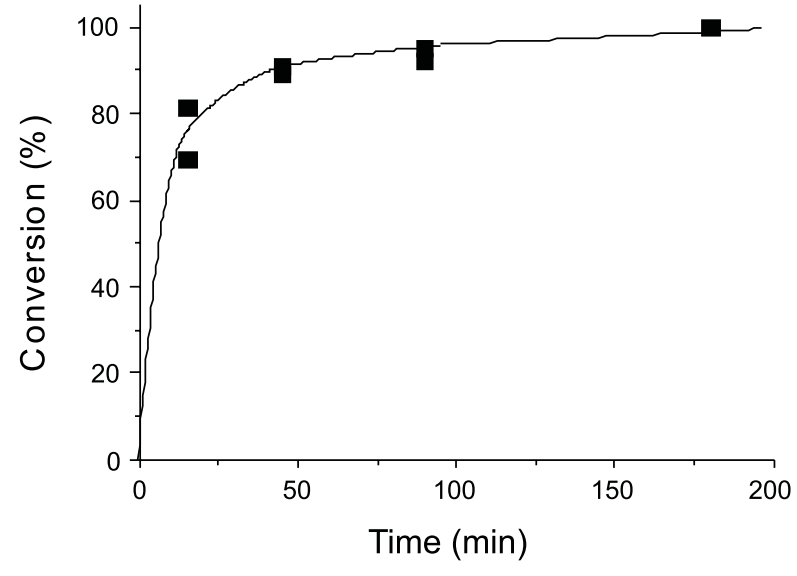

Figure 8S. Effect of reaction time on conversion of phenylsulfonylacetonitrile at $383 \mathrm{~K}$, using $5 \mathrm{wt}$ \% of catalyst MO20 (atmospheric pressure, phenylsulfonilacetonitrile/benzaldehyde $=1$ (molar) 